\title{
The Location Inventory Routing Optimization Model and Algorithm for the Islands Shipping Network
}

\section{Di Wu}

Dalian Maritime University

Nuo Wang ( $\square$ wangnuodl@126.com )

Dalian Maritime University

\section{Research Article}

Keywords: Shipping network, port, location, inventory, routing, optimization

Posted Date: April 21st, 2021

DOl: https://doi.org/10.21203/rs.3.rs-162739/v1

License: (c) (1) This work is licensed under a Creative Commons Attribution 4.0 International License. Read Full License 


\title{
The location inventory routing optimization model and
}

\section{algorithm for the islands shipping network}

\author{
Di Wu, Nuo Wang* \\ (School of Transportation Engineering, Dalian Maritime University, Dalian 116026, China.)
}

Nuo Wang (corresponding author): a professor at School of Transportation Engineering, Dalian Maritime University. Email: wangnuodl@126.com

Di Wu (first author): a lecturer at School of Transportation Engineering, Dalian Maritime

University. Email: wudidlmu@163.com 


\title{
The location inventory routing optimization model and
}

\section{algorithm for the islands shipping network}

\begin{abstract}
This paper studies a hub-and-spoke shipping network of islands and integrates a maritime location inventory routing problem (MLIRP) for the islands shipping network. By determining a series of decisions including the location of the hub islands, the number of shipping routes, the schedule of every route, the running mode of every route, the ship size, the wharf scale and the inventory capacity, the objective of the paper is to minimize the total cost of the islands shipping network. For solving the integrated MLIRP model, a hybrid genetic algorithm based on the stepwise configuration (SC-GA) is presented. Finally, instances are put forward to evaluate the performance of the algorithm. The results of sensitivity analysis show that the wharf construction cost affects the total costs the most, so more attention should be paid to it when making decisions. This paper can provide theoretical and practical information to design and optimize an islands shipping network.
\end{abstract}

Key words: Shipping network; port; location; inventory; routing; optimization

\section{Introduction}

Generally, islands are far away from the mainland and have extremely poor supply and infrastructure. The residents on islands have to rely on the supplies from the mainland, and thus ships frequently run between the mainland and islands and archipelago inside. In this setting, a closed and hub-and-spoke islands shipping network is developed. In the network, there are strong correlations between the location of the hub islands, the number of shipping routes, the schedule of every route, the running mode of every route, the ship size, the wharf scale and the inventory capacity. Therefore, the paper considers a maritime location-inventory-routing problem (MLIRP) with deterministic demand, multi-size carrier, and multi-running-mode.

More recently, related studies about the location, inventory and routing problems have been widely concerned (Jayaraman, 1998; Nozick and Turnquist, 2001; Liu and Lee, 2003; Liu and Lee, 2005; Ambrosino and Scutella, 2005; Shen and Qi, 2007; Javid and Azad, 2010; Nekooghadirli et 
al., 2014). Related concerns of the location-inventory problem (LIP), inventory-routing problem (IRP), location-routing problem (LRP), and location-inventory-routing problem (LIRP) have also gathered an increased attention.

With respect to the LIP, Shen et al. (2003) studied the problem by allowing some retailers to serve as distribution centres for other retailers to reduce the cost of inventory and structured a set-covering integer-programming model. For the LRP, Tuzun and Burke (1999) expounded on the interdependent relationship of location and routing. Wu et al. (2002) studied the multi-distribution centre location and routing problem. They divided the original problem into two sub-problems, the location-allocation problem and the general routing problem, and used anneal arithmetic to solve them. For the IRP, Viswanathan and Mathur (1997) noted that the core of IRP is how to optimize the inventory replenishment strategy and routing to minimize the sum of the long-term inventory costs and transportation costs. Song and Furman (2013) introduced a flexible modelling framework for IRP that can accommodate various practical features. What's more, for the LIRP, Guerrero et al. (2015) proposed a partition using a Dantzig-Wolfe formulation on the routing variables and presented a heuristic with hybridization between column generation, Lagrangian relaxation, and local search to solve the LIRP. Liu et al. (2015) studied a three-phase supply chain distribution system consisting of one supplier, a set of retailers, and a single product with a continuous review $(\mathrm{Q}, \mathrm{r})$ inventory policy, and a pseudo-parallel genetic algorithm integrating simulated annealing was proposed.

In addition, previous studies about the MLIRP have been relatively few recently (Ronen, 2002; Hsu and Hsieh, 2007). For example, Christiansen et al. (2011) and Uggen et al. (2013) developed heuristic algorithms to solve the problem. The former established the model by fleet transport capacity constraints and then proposed a construction heuristic embedded in a genetic algorithm framework. The latter presented a new way of optimizing MIRP by using a heuristics based on fix-and-relax time decomposition. In addition, Engineer et al. (2012), Hewitt et al. (2013), and Rakke et al. (2015) used the branch and bound method to solve MIRP. Due to ship routing with uncertainty in weather conditions and unpredictable waiting times at ports, Agra et al. (2015) considered stochastic sailing time and port time, and a two-stage stochastic programming 
model with recourse was presented where the first stage consists of routing, loading, and unloading decisions and the second stage consists of scheduling and inventory decisions.

The islands shipping network design is the generalization of maritime transport network optimization problem (MTNOP). Nowadays, there are a large number of studies of MTNOP (Iakovou et al. 1999; Gelareh et al., 2010; Meng and Wang, 2011; Reinhardt and Pisinger, 2012; Wang et al., 2013; Brouer et al., 2014; Wang and Meng; 2014; Tran and Haasis, 2015). For example, Agarwal and Ergun (2008) presented an integrated model, a mixed-integer linear program, to solve the ship-scheduling and cargo-routing problems simultaneously. Moreover, some scholars focused on the hub-and-spoke marine transport network. Dong et al. (2015) proposed a two-stage stochastic programming model with recourse to address MTNOP, with the first stage determining the optimal service capacity and the second focused on the optimal routing of shipments. Although the two-stage method can solve the problem, it cannot comprehensively consider all cases in the solving process. Jin (2003) and Xu et al. (2007) studied the ship-transport network of China and the surrounding area. The former discussed the strategies of shipping centres and the transport network, and the latter found that geographical constraints plays an important role in the network topology of the ship-transport network of China.

Despite a wide range of studies about MTNOP and related LIRPs, few studies involve an islands transport system with multi-size carrier and multi-running-mode. Therefore, this paper considers a MLIRP for an islands shipping network. The contributions of the paper are as follows: The islands shipping network is a closed system where ships run inside the network only, and it is essentially different from general maritime networks that are open. In the closed islands network, there are strong relations among routing, ships and wharf, but the optimization of transportation costs, construction costs and inventory costs may be contrary. To minimize the total cost under the precondition of uninterrupted supply, this paper considers the location of the hub islands, the number of shipping routes, the schedule of every route, the running mode of every route, the ship size, the wharf scale and the inventory capacity. Finally, for solving the MLIRP, we introduce a genetic algorithm based on the stepwise configuration (SC-GA) and evaluate its performance.

The rest of this paper is organized as follows: In Section 2, the MLIRP with deterministic 
demand, multi-size carrier and multi-running-mode is formulated. Section 3 presents a genetic algorithm based on the stepwise configuration that can optimize the problem. Section 4 describes computational experiments to evaluate the performance of the SC-GA. Section 5 presents the conclusions and provides insights towards future research topics.

\section{Mathematics model}

\subsection{Problem description}

The island shipping network usually consists of the mainland, the hub islands and the satellite islands. In the network, the supplies are transported from the mainland to the hub island via the main network and then distributed from the hub island to its satellite islands via the branch network. Since the islands shipping network is a one-way closed transport network, there are some complicated problems in this network. To minimize the total cost under the precondition of uninterrupted supply, we need to optimize the location of hub islands, the routes in the main network and branch network, the running mode of every route, and the ship size and schedule of every route, wharf scale and inventory capacity and cycle supply of every island. For instance, if we use a large ship in a route and try to load it fully, it can prolong the schedule and reduce the shipping cost, but it will lead to increasing wharf and warehouse construction costs, which may increase the total cost. Hence, the overall network needs to be determined as a whole.

\subsection{Notation}

The notations used in the paper are listed as follows, unless otherwise specified (Table 1).

Table 1 List of notations

\begin{tabular}{ll}
\hline Sets & a set of archipelagos (i.e., islands groups), $k \in K$ \\
$K$ & a set of islands in archipelago $k, p^{k} \in P^{k}$ \\
$P^{k}$ & a set of alternative ship size, $s \in S$. \\
$S$ & a set of BFRG in the branch network, $\phi=1,2, \cdots, n$ \\
$\phi$ & s set of CR in the branch network, $\psi=1,2, \cdots, z$ \\
$\psi$ & a set of BFRG in the main network, $u=1,2, \cdots, w$ \\
$u$ & a set of CR in the main network, $v=1,2, \cdots, e$ \\
$v$ & the mainland port \\
Parameters & the number of the island \\
$\xi$ &
\end{tabular}




\begin{tabular}{|c|c|}
\hline$\lambda^{k}$ & the number of island in archipelago $k$. \\
\hline$C_{d r}, C_{c y}$ & the total shipping costs of the BFRG and the CR in the branch network, respectively \\
\hline$C_{m d r}, C_{m c y}$ & the total shipping costs of the BFRG and CR in the main network, respectively \\
\hline$C_{\text {ship }}$ & the ship using cost \\
\hline$C_{\text {port }}$ & the wharf construction cost \\
\hline$C_{s t f}, C_{s t b}$ & the inventory cost and warehouse construction cost, respectively \\
\hline$l_{i, j}$ & the distance between island $i$ and island $j$ \\
\hline$\gamma$ & ship speed \\
\hline $\begin{array}{l}t_{\text {all }} \\
\text { variables }\end{array}$ & the total time of system operation \\
\hline$m^{k}$ & the hub island in archipelago $k$, where $m^{k}=\sum_{p^{k} \in P^{k}} a_{p^{k}}^{\text {main }} p^{k}$ \\
\hline$N_{\psi}$ & $\begin{array}{l}\text { the number of islands passed through by the CR } \psi \text { in the branch network, e.g., if the CR } 3 \\
\text { in the branch network is } 2^{\#} \rightarrow 3^{\#} \rightarrow 7^{\#} \rightarrow 1^{\#} \rightarrow 2^{\#} \text {, then } N_{3}=5 \text {. }\end{array}$ \\
\hline$N_{v}$ & $\begin{array}{l}\text { the number of islands passed through by } \mathrm{CR} v \text { in the main network. } \\
\text { the } g \text { th island of } \mathrm{CR} \psi \text { in the branch network, e.g., if CR } 3 \text { in the branch network is }\end{array}$ \\
\hline$d_{g}^{\psi}$ & $2^{\#} \rightarrow 3^{\#} \rightarrow 7^{\#} \rightarrow 1^{\#} \rightarrow 2^{\#}$, then $d_{2}^{3}=3$ \\
\hline$r_{h}^{v}$ & $\begin{array}{l}\text { the } h \text { th island of } \mathrm{CR} v \text { in the main network, e.g., if } \mathrm{CR} 1 \text { in the main network is } \\
o \rightarrow 2^{\#} \rightarrow 15^{\#} \rightarrow 22^{\#} \rightarrow o \text {, then } r_{2}^{1}=2 \text {. }\end{array}$ \\
\hline$t_{\phi}, t_{\psi}$ & the shipping schedule of the BFRG $\phi$ and the CR $\psi$ in the branch network, respectively \\
\hline $\begin{array}{l}t_{u}, t_{v} \\
\text { decision variables }\end{array}$ & the shipping schedule of the BFRG $u$ and the CR $v$ in the main network, respectively \\
\hline$a_{p^{k}}^{\phi}$ & if BFRG $\phi$ transports for island $p^{k}, a_{p^{k}}^{\phi}=1$; otherwise, $a_{p^{k}}^{\phi}=0$ \\
\hline$a_{p^{k}}^{\psi}$ & if CR $\psi$ transports for island $p^{k}, a_{p^{k}}^{\psi}=1$; otherwise, $a_{p^{k}}^{\psi}=0$ \\
\hline$b_{s}^{\phi}$ & if the ship size of BFRG $\phi$ is $s, b_{s}^{\phi}=1$ \\
\hline$b_{s}^{\psi}$ & if the ship size of CR $\psi$ is $s, b_{s}^{\psi /}=1$ \\
\hline$b_{s}^{u}$ & if the ship size of BFRG $u$ is $s, b_{s}^{u}=1$ \\
\hline$b_{s}^{v}$ & if the ship size of CR $v$ is $s, b_{s}^{v}=1$ \\
\hline
\end{tabular}

\subsection{Model formulation}

\subsubsection{Transportation cost model}

This paper divides the running mode of the route into two types: back-and-forth routing (BFR) 
that transports between a hub island and a satellite island, and cycle routing (CR) that transports among a hub island and several satellite islands. Since one ship may serve two or more BFRs, we define the scenario as a back-and-forth routing group (BFRG). For example, three routes between a hub island and satellite islands $1^{\#}, 5^{\#}$ and $4^{\#}$ are served by one ship, so that the three routes are a BFRG. Thus, the shipping cost model can be stated as follows:

$$
\begin{gathered}
C_{d r}=\sum_{\phi=1}^{n} \sum_{k \in K} \sum_{p^{k} \in P^{k}} 2 l_{m^{k}, p^{k}} a_{p^{k}}^{\phi} \sum_{s \in S} b_{s}^{\phi} c_{s}^{t r} \frac{t_{\text {all }}}{t_{\phi}} \\
C_{c y}=\sum_{\psi=1}^{z} \sum_{g=1}^{N_{\psi}-1} l_{d_{g}^{\psi}, d_{g-1}^{\psi}} \sum_{s \in S} b_{s}^{\psi} c_{s}^{t r} \frac{t_{a l l}}{t_{\psi}} \\
C_{m d r}=\sum_{u=1}^{w} \sum_{k \in K} 2 l_{o, m^{k}} a_{m^{k}}^{u} \sum_{s \in S} b_{s}^{u} c_{s}^{t r} \frac{t_{a l l}}{t_{u}} \\
C_{m c y}=\sum_{v=1}^{e} \sum_{h=1}^{N_{v}-1} l_{r_{h}^{v}, r_{h-1}^{v}} \sum_{s \in S} b_{s}^{v} c_{s}^{t r} \frac{t_{a l l}}{t_{v}}
\end{gathered}
$$

where $c_{s}^{t r}$ is the shipping cost per nautical mile of the $s$-type ship. Eqs. (1) and (2) are the sum of the shipping costs of all the BFRGs and the CRs in the branch network during the total time of operation. Eqs. (3) and (4) are the sums of shipping costs of all the BFRGs and CRs in the main network during the total time of operation.

Then, the ship using cost model can be stated as follows:

$$
\begin{gathered}
C_{\text {ship }}=\sum_{\phi=1}^{n} \sum_{s \in S} b_{s}^{\phi} c_{s}^{p r o}+\sum_{\psi=1}^{z} \sum_{s \in S} b_{s}^{\psi} c_{s}^{p r o}+\sum_{u=1}^{w} \sum_{s \in S} b_{s}^{u} c_{s}^{p r o}+\sum_{v=1}^{e} \sum_{s \in S} b_{s}^{v} c_{s}^{p r o}+ \\
\left(\sum_{\phi=1}^{n} \sum_{s \in S} b_{s}^{\phi} c_{s}^{r u n}+\sum_{\psi=1}^{z} \sum_{s \in S} b_{s}^{\psi} c_{s}^{r u n}+\sum_{u=1}^{w} \sum_{s \in S} b_{s}^{u} c_{s}^{r u n}+\sum_{v=1}^{e} \sum_{s \in S} b_{s}^{v} c_{s}^{r u n}\right) \cdot \frac{12 t_{\text {all }}}{365}(5)
\end{gathered}
$$

where $c_{s}^{\text {pro }}$ and $c_{s}^{\text {run }}$ are the purchase cost and monthly maintenance cost of the $s$-type ship. Eq. (5) is the sum of the ship purchase costs and monthly maintenance costs during the total operation time of all the BFRGs and CRs in the branch network and the main network.

\subsubsection{Wharf construction cost model}

Then, the wharf construction cost model can be stated as follows: 


$$
\begin{gathered}
C_{\text {port }}=\sum_{\phi=1}^{n} \sum_{k \in K} \sum_{p^{k} \in P^{k}} a_{p^{k}}^{\phi} \sum_{s \in S} b_{s}^{\phi} c_{s}^{\text {port }}+\sum_{\psi=1}^{z}\left(N_{\psi}-2\right) \sum_{s \in S} b_{s}^{\psi} c_{s}^{p o r t}+\sum_{u=1}^{w} \sum_{k \in K} a_{m^{k}}^{u} \sum_{s \in S} b_{s}^{u} c_{s}^{\text {port }}+ \\
\sum_{v=1}^{e} \sum_{k \in K} a_{m^{k}}^{v} \sum_{s \in S} b_{s}^{v} c_{s}^{\text {port }}+\sum_{k \in K} \sum_{s \in S} b_{s}^{k} c_{s}^{\text {port }}
\end{gathered}
$$

where $c_{s}^{\text {port }}$ is the construction cost of a wharf in which $s$-type ship can berth. In Eq. (6), the first and second items are the sums of the wharf construction costs of all the satellite islands respectively passed through by BFRGs and CRs in the branch network, the third and the fourth items are the sums of the wharf construction cost of all hub islands respectively passed through by BFRGs and CR in the main network, and the fifth item is the sum of the construction costs of all hub island wharfs corresponding to ship sizes appearing in the branch network of every island.

\subsubsection{Inventory cost model}

In the islands shipping network, all shipping has to interrupt when the tropical cyclone comes, so that the daily consumption of each island will be supplied by its inventory until the tropical cyclone is over. Thus, the minimum inventory $Q_{\text {risk }}$ is proposed to resist the risk of tropical cyclone, and it can be given by

$$
Q_{\text {risk }}=\Delta t \cdot q
$$

where $\Delta t$ is the number of days that the minimum inventory of every island can supply its daily consumption, and $q$ is the average daily consumption.

In this paper, we make the following assumptions. (1) The daily consumption of each island is continuous and deterministic. (2) The inventory time is in the start of each period, and $Q_{\text {sup }}$ denotes the supply. Therefore, the inventory state function is as follows: $I(\tau)=Q_{\text {all }}-q \tau$, $\tau \in[0, t]$, where $Q_{\text {all }}$ denotes inventory capacity, and $t$ is the shipping schedule of the route (supply cycle of the island). The supply should be replenished to $Q_{a l l}$ when the inventory state $I(\tau)=Q_{\text {all }}-q t$, so $Q_{\text {sup }}=q t$ and $Q_{\text {all }}=Q_{\text {sup }}+Q_{\text {risk }}$. According to the inventory state (Fig. 1), the supply in the period of $[0, t]$ can be given by, 


$$
\int_{0}^{t} I(\tau) d \tau=\int_{0}^{t}\left(Q_{\text {all }}-q t\right) d \tau=\left(Q_{\text {sup }}+Q_{\text {risk }}\right) t-\frac{1}{2} q t^{2}=\Delta t q t+\frac{1}{2} q t^{2}
$$

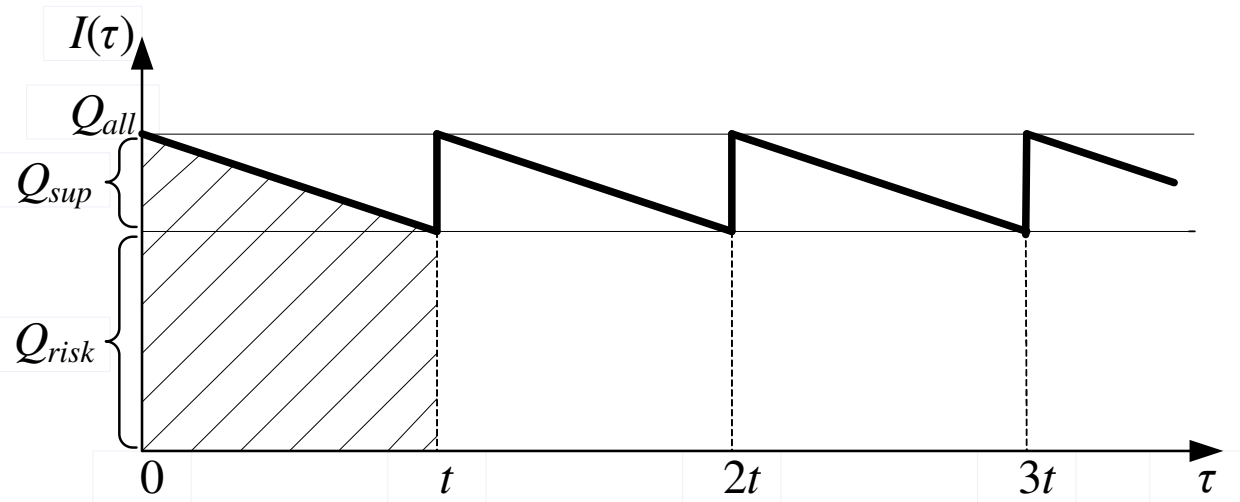

Fig. 1. Inventory state

According to Eq. (8), $q_{m^{k}}$ is the average daily consumption of the hub island $k ; q_{p^{k}}$ is the average daily consumption of satellite island $p^{k}$ passed though by a BFR; the decision variables $a_{\psi}^{k}=1$ if the $\mathrm{CR} \psi$ of the branch network is running in island $k$. Then, the inventory cost model and the warehouse construction cost model can be stated as follows:

$$
\begin{aligned}
C_{s t f}= & \sum_{\phi=1}^{n} \sum_{k \in K} \sum_{p^{k} \in P^{k}} a_{p^{k}}^{\phi}\left(\frac{1}{2} q_{p^{k}} t_{\phi}^{2}+\Delta t q_{p^{k}} t_{\phi}\right) \frac{t_{\text {all }}}{t_{\phi}}+\sum_{\psi=1}^{z} \sum_{g=2}^{N_{\psi}-1}\left(\frac{1}{2} q_{d_{g}^{\psi}} t_{\psi}^{2}+\Delta t q_{d_{g}^{\psi}} t_{\psi}\right) \frac{t_{\text {all }}}{t_{\phi}}+ \\
& \sum_{u=1}^{w} \sum_{k \in K} a_{m^{k}}^{u}\left[\frac{1}{2}\left(\sum_{\phi=1}^{n} \sum_{p^{k} \in P^{k}} a_{p^{k}}^{\phi} q_{p^{k}}+\sum_{\psi=1}^{z} a_{\psi}^{k} \sum_{g=2}^{N_{\psi}-1} q_{d_{g}^{\psi}}+q_{m^{k}}\right) t_{u}^{2}+\Delta t q_{m^{k}} t_{u}\right] \frac{t_{\text {all }}}{t_{u}}+ \\
& \sum_{v=1}^{e} \sum_{k \in K} a_{m^{k}}^{v}\left[\frac{1}{2}\left(\sum_{\phi=1}^{n} \sum_{p^{k} \in P^{k}} a_{p^{k}}^{\phi} q_{p^{k}}+\sum_{\psi=1}^{z} a_{\psi}^{k} \sum_{g=2}^{N_{\psi}-1} q_{d_{g}^{\psi}}+q_{m^{k}}\right) t_{v}^{2}+\Delta t q_{m^{k}} t_{v}\right] \frac{t_{\text {all }}}{t_{v}} \\
& C_{s t b}=\left\{\sum_{\phi=1}^{n} \sum_{k \in K} \sum_{p^{k} \in P^{k}} a_{p^{k}}^{\phi} q_{p^{k}}\left(\Delta t+t_{\phi}\right)+\sum_{\psi=1}^{z} \sum_{g=2}^{N_{\psi}-1} q_{d_{g}^{\psi}}\left(\Delta t+t_{\psi}\right)+\right. \\
& \sum_{u=1}^{w} \sum_{k \in K} a_{m^{k}}^{u}\left[\left(\sum_{\phi=1}^{n} \sum_{p^{k} \in P^{k}} a_{p^{k}}^{\phi} q_{p^{k}}+\sum_{\psi=1}^{z} a_{\psi}^{k} \sum_{g=2}^{N_{\psi}-1} q_{d_{g}^{\psi}}+q_{m^{k}}\right) t_{u}+q_{m^{k}} \Delta t\right]+ \\
& \left.\sum_{v=1}^{e} \sum_{k \in K} a_{m^{k}}^{v}\left[\left(\sum_{\phi=1}^{n} \sum_{p^{k} \in P^{k}} a_{p^{k}}^{\phi} q_{p^{k}}+\sum_{\psi=1}^{z} a_{\psi}^{k} \sum_{g=2}^{N_{\psi}-1} q_{d_{g}^{\psi}}+q_{m^{k}}\right) t_{v}+q_{m^{k}} \Delta t\right]\right\} c_{b u l d}
\end{aligned}
$$


where Eq. (9) is the sum of the inventory costs of all islands passed through by the BFRGs and CRs in the branch network and the main network. Eq. (10) is the sum of the warehouse construction costs of all islands passed through by BFRGs and CRs in the branch network and the main network.

\subsubsection{Formulation}

The integrated MLIRP model can thus be described as the following formulations:

$$
\begin{aligned}
& \text { Minimize } C_{\text {total }}=C_{d r}+C_{c y}+C_{m d r}+C_{m c y}+C_{s h i p}+C_{p o r t}+C_{s t f}+C_{s t b} \\
& \text { s.t. } \sum_{\phi=1}^{n} a_{p^{k}}^{\phi}+\sum_{\psi=1}^{z} a_{p^{k}}^{\psi} \leq 1, k \in K, p^{k} \in P^{k} \\
& \sum_{p^{k} \in P^{k}}\left(\sum_{\phi=1}^{n} a_{p^{k}}^{\phi}+\sum_{\psi=1}^{z} a_{p^{k}}^{\psi}\right)=\lambda^{k}-1, k \in K \\
& \sum_{u=1}^{w} a_{m^{k}}^{u}+\sum_{v=1}^{e} a_{m^{k}}^{v} \leq 1, k \in K \\
& \sum_{k \in K}\left(\sum_{u=1}^{w} a_{m^{k}}^{u}+\sum_{v=1}^{e} a_{m^{k}}^{v}\right)=\xi \\
& a_{p^{k}}^{\phi} q_{p^{k}} t_{\phi} \leq \sum_{s \in S} b_{s}^{\phi} s, \quad k \in K, p^{k} \in P^{k}, \phi=1,2, \cdots, n \\
& \sum_{g=2}^{N_{\psi}-1} q_{d_{g}^{\psi}} t_{\psi} \leq \sum_{s \in S} b_{s}^{\psi} s, \psi=1,2, \cdots, z \\
& \text { (17) } a_{m^{k}}^{u}\left(\sum_{\phi=1}^{n} \sum_{p^{k} \in P^{k}} a_{p^{k}}^{\phi} q_{p^{k}}+\sum_{\psi=1}^{z} a_{\psi}^{k} \sum_{g=2}^{N_{\psi}-1} q_{d_{g}^{\psi}}+q_{m^{k}}\right) t_{u} \leq \sum_{s \in S} b_{s}^{u} s, \quad k \in K, \quad u=1,2, \cdots, w \\
& \sum_{k \in K} a_{m^{k}}{ }^{k}\left[\left(\sum_{\phi=1}^{n} \sum_{p^{k} \in P^{k}} a_{p^{k}}^{\phi} q_{p^{k}}+\sum_{\psi=1}^{z} a_{\psi}^{k} \sum_{g=2}^{N_{\psi}-1} q_{d_{g}^{\psi}}+q_{m^{k}}\right) t_{v} \leq \sum_{s \in S} b_{s}^{v} s, \quad v=1,2, \cdots, e\right. \\
& \left\{\sum_{p^{k} \in P^{k}} a_{p^{k}}^{\phi}+2 \sum_{p^{k} \in P^{k}} l_{m^{k}, p^{k}} a_{p^{k}}^{\phi} / \gamma\right\} \leq \max \left\{\left\{\left(\sum_{p^{k} \in P^{k}} a_{p^{k}}^{\phi}\right) / \lambda^{k}\right\}, 0\right\} t_{\phi} \leq \\
& {\left[\max \left\{a_{p^{k}}^{\phi} \max \{S\} / q_{p^{k}} \mid p^{k} \in P^{k}\right\}\right], k \in K, \phi=1,2, \cdots, n}
\end{aligned}
$$




$$
\begin{array}{r}
\left\{\left(N_{\psi}-1\right) / 2+\sum_{g=1}^{N_{\psi}-1} l_{d_{g}^{\psi}, d_{g-1}^{\psi}} / \gamma\right\} \leq t_{\psi} \leq\left[\max \{S\} / \sum_{g=2}^{N_{\psi}-1} q_{d_{g}^{\psi}}\right], \psi=1,2, \cdots, z \\
\left\{\sum_{k \in K} a_{m^{k}}^{u}+2 \sum_{k \in K} l_{o, m^{k}} a_{m^{k}}^{u} / \gamma\right\} \leq t_{u} \leq\left[\max \left\{a_{m^{k}}^{u} \max \{S\} / q_{m^{k}} \mid k \in K\right\}\right], u=1,2, \cdots, w \\
\left\{\left(N_{v}-1\right) / 2+\sum_{h=1}^{N_{v}-1} l_{d_{h}^{v}, d_{h-1}^{v}} / \gamma\right\} \leq t_{v} \leq\left[\max \{S\} / \sum_{h=2}^{N_{v}-1} q_{d_{h}^{v}}\right], v=1,2, \cdots, e
\end{array}
$$

The objective function Eq. (11) is the total logistics cost during the whole operation period. Constraints (12) and (13) show that, in the branch network, there is only one route from a hub island to its each satellite island. Constraints (14) and (15) show that, in the main network, from the mainland to the hub island there is only one route. Constraint (16) shows that the cycle supply of every satellite island transported by BFR should not exceed the deadweight of the ship equipped on the BFRGs. Constraint (17) shows that the total cycle supply of satellite islands transported by any $\mathrm{CR}$ in the branch network should not exceed the deadweight of the ship equipped on the CRs. Constraint (18) shows that the cycle supply of every hub island transported by the BFR should not exceed the deadweight of the ship equipped on the BFRGs. Constraint (19) shows that the total cycle supply of the hub islands transported by any CR in the main network should not exceed the deadweight of the ship equipped on the CR. Constraints (20) and (21) respectively show the value range of the schedule of the BFRGs and CRs in the branch network. Constraints (22) and (23) respectively show the value range of the schedule of BFRGs and CRs in the main network.

\section{Algorithm}

The MLIRP with multi-size carrier and multi-running-mode is an NP-hard problem. For solving it, we develop a genetic algorithm based on the stepwise configuration (SC-GA). The steps of SC-GA are as follows. (1) Based on the chromosome, obtain the location of each hub island, the number of routes of main network and branch network, which islands are passed through by each route and the sequence of the islands. (2) Using the stepwise configuration module (SC module), stepwise optimize and configure the branch network and main network route parameters (ship size, schedule, cycle transport volume and running mode of every route) 
and inventory parameters (cycle supply and inventory capacity), and then calculate the objective function of the chromosome. (3) Get the optimal solution of the model by iterations.

\subsection{Chromosome representation}

To express the information of the location of each hub island, the number of routes of the main network and branch network, which islands are passed through by each route and the sequence of the islands, we design the chromosome respectively for the main and branch networks by the manner of saturated division to fully express the whole solution space (under an extreme situation, all routes are BFRs and transported by respective ships). That is to say, a chromosome consists of the shipping network gene segment of transport from the mainland to hub islands (shorted as hub island gene segment) and the shipping network gene segments of transport from the hub island to its satellite islands (shorted as each island gene segment), and we use n-1 (assuming a gene segment contain $\mathrm{n}$ islands) separators to divide the gene segment into $\mathrm{n}$ segments, so the gene between two separators signifies the islands in one group. One possible chromosome is shown in Fig. 2.

\begin{tabular}{|c|c|c|c|c|c|c|c|c|c|c|c|c|}
\hline \multirow{4}{*}{ chromosome: } & \multirow{2}{*}{$\begin{array}{l}\text { center island gene segment: } \\
\text { archipelago } 1 \text { gene segment: }\end{array}$} & 10 & 14 & 0 & 2 & 0 & & & & & & \\
\hline & & 6 & 4 & 0 & 0 & 1 & 7 & 3 & 0 & 0 & 0 & 5 \\
\hline & archipelago 2 gene segment: & 0 & 11 & 9 & 0 & 0 & 8 & 12 & 0 & & & \\
\hline & archipelago 3 gene segment: & 13 & 16 & 0 & 18 & 0 & 0 & 17 & 15 & 0 & & \\
\hline
\end{tabular}

Fig. 2. Chromosome expression

In Fig. 2, the hub island gene segment means that island $2^{\#}, 10^{\#}$, and $14^{\#}$ are respectively the hub islands 1,2, and 3; there are two route groups in the main network, and they are respectively transport from mainland to island $10^{\#}$ and $14^{\#}$ successively (using the same ship) and from mainland to island $2^{\#}$. The island $1^{\#}$ gene segment means that there are three routes in island $1^{\#}$ of the branch network, and they are respectively transport from island $2^{\#}$ to island $6^{\#}$ and $4^{\#}$ successively (using the same ship), from island $2^{\#}$ to island $1^{\#}, 7^{\#}$, and $3^{\#}$ successively (using the same ship) and from island $2^{\#}$ to island $5^{\#}$. The island 2 gene segment means that there are two 
routes in island 2 of the branch network, and they are respectively transport from island $10^{\#}$ to island $11^{\#}$ and $9^{\#}$ successively (using the same ship) and from island $10^{\#}$ to island $8^{\#}$ and $12^{\#}$ successively (using the same ship). The island 3 gene segment means that there are three routes in island 3 of the branch network, and they are respectively transport from island $14^{\#}$ to island $13^{\#}$ and $16^{\#}$ successively (using the same ship), from island $14^{\#}$ to island $18^{\#}$ and from island $14^{\#}$ to island $17^{\#}$ and $15^{\#}$ successively (using the same ship). The above information expressed in the chromosomes encoding the hub island location and routing will provide data support for the SC module.

\subsection{SC module}

The cycle supply and inventory capacity of each island transported by same route are determined by the route's shipping schedule $t$, the ship size of any route in the branch and main network under different running mode is determined by the cycle supply of each island transported by the same route, the wharf scale of each island transported by same route is determined by the ship size of the route; and the range of $t$ can be obtained according to Eqs. (20-23). Then, we regard $t$ as an independent variable and regard the cycle supply, inventory capacity, ship size, wharf scale, total costs of route and inventory as dependent variables of every route in the branch and main network under different running modes. Thus, the steps of SC module are as follows:

For a route of the branch network, we use the enumeration method, taking $t$ as an independent variable, to calculate the minimum total costs respectively under back-and-forth transport and cycle transport running mode, choose the running mode with the lower minimum total cost and the corresponding shipping schedule, ship size, wharf scale and cycle supply and inventory capacity of every island passed though by this route as the optimal configuration solution of this route. Then, according to the above method, we successively optimize and configure all routes in the branch network. (2) We take the total daily consumption of every island as the daily consumption of every hub island; (3) For a route of the main network, we use the enumeration method, taking $t$ as an independent variable, to calculate the minimum total costs respectively under back-and-forth transport and cycle transport running mode, choose the running mode with the 
lower minimum total cost and the corresponding shipping schedule, ship size, wharf scale and cycle supply and inventory capacity of every island passed though by this route as the optimal configuration solution of this route. Then, according to above method, we successively optimize and configure all routes in the main network. The procedure is described as follows:

Step 1: Decode the information of the hub island location and a route in branch network from the chromosome.

Step 2: Set the value range of schedule $t$ of the route under back-and-forth transport and cycle transport running modes according to Eq. (20) and Eq. (21).

Step 3: Use an exhaustive method, taking $t$ as an independent variable, calculate the minimum total costs of the route under the back-and-forth and cycle transport running modes.

Step 4: Choose the running mode with the lower minimum total cost, and define the corresponding shipping schedule, ship size, wharf scale and cycle supply and inventory capacity of each island as the optimal configuration solution of the route.

Step 5: Repeat step 1 to step 4 , and configure all routes in the branch network.

Step 6: Take the total daily consumption of every island as the daily consumption of every hub island.

Step 7: Decode the information of the hub island location and a route in main network from the chromosome.

Step 8: Set the value range of schedule $t$ of the route under the back-and-forth transport and cycle transport running modes according to Eq. (22) and Eq. (23).

Step 9: Use the exhaustive method, taking $t$ as the independent variable, to calculate the minimum total costs the route under the back-and-forth and cycle transport running modes.

Step 10: Choose the running mode with the lower minimum cost, and define the corresponding shipping schedule, ship size, wharf scale, cycle supply and inventory capacity of each island as the optimal configuration solution of the route.

Step 11: Repeat step 7 to step 10, and configure all routes in the main network.

Step 12: Output the total cost of the chromosome and the optimal configuration solution of every route in the branch and main networks. 
The specific steps are shown in Fig. 3.

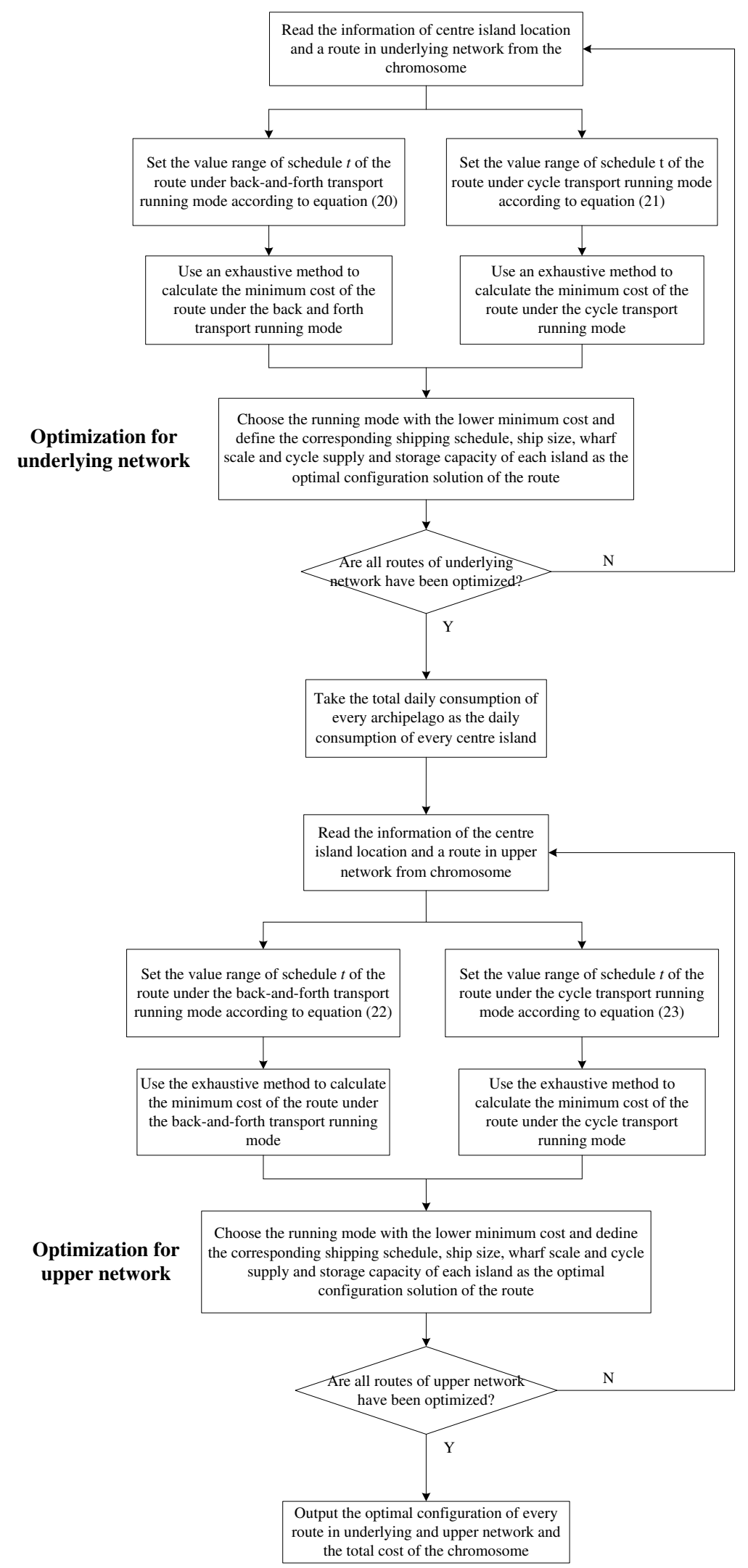


Fig. 3. Framework of SC module

\subsection{Fitness}

For each chromosome in SC-GA, the fitness value is equal to the total cost of the chromosome obtained by the SC module. Obviously, the lower the fitness value is, the better the chromosome is.

\subsection{Crossover}

According to the characteristics of chromosome, the delimiters and the island are crossed respectively in the crossover operator of SC-GA. This means that the offspring inherits the position of delimiters in parent 1 and the order of island numbers in parent 2. An example of the crossover operator is shown in Fig. 4.

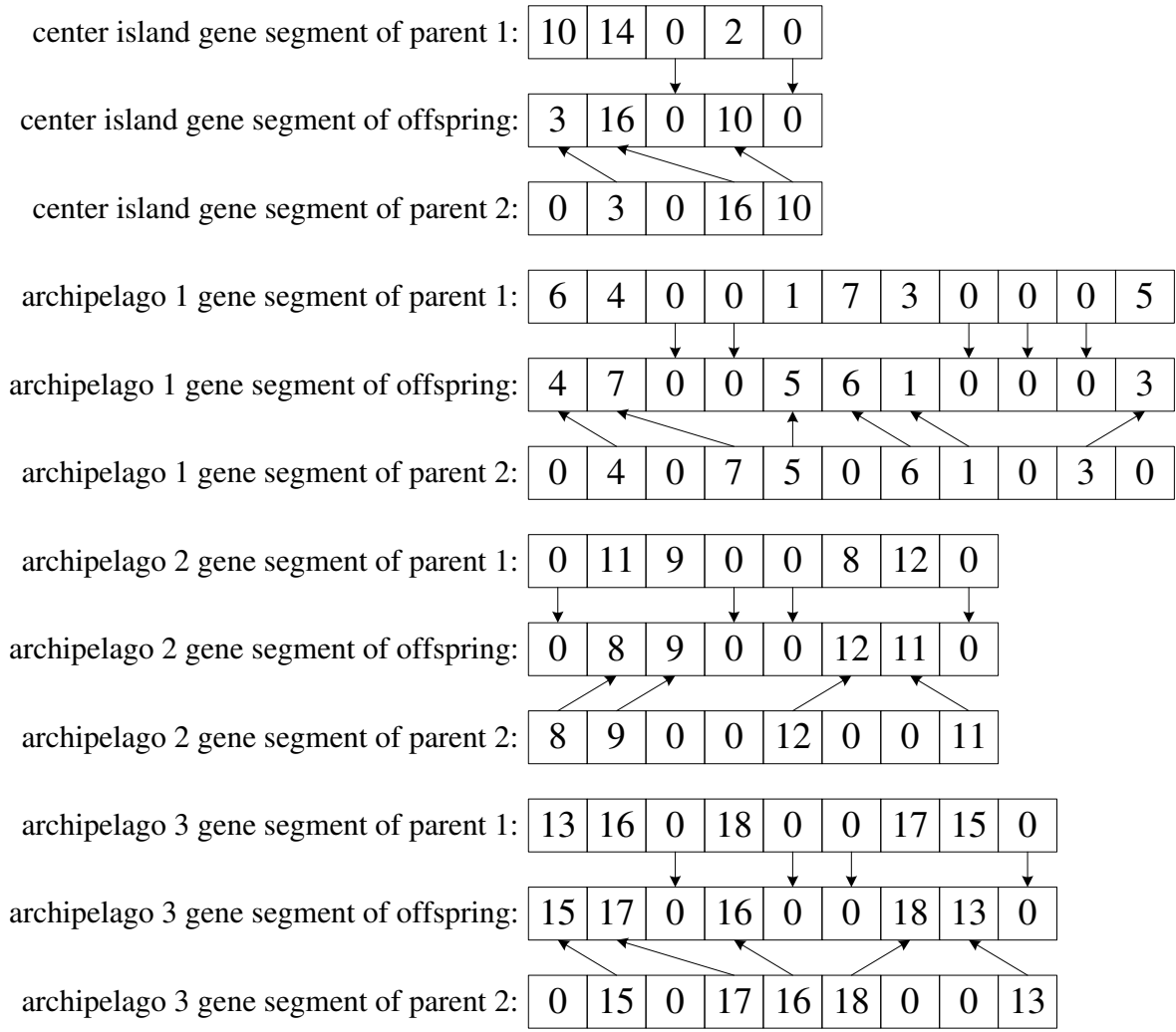

Fig. 4. crossover operator

\subsection{Mutation}

Due to complex chromosomes, the mutation operator of SC-GA has three different methods. The first operator is the exchange between island numbers in the same gene segment; the second is 
the exchange between the delimiter and island number in the same gene segment; and the third is the exchange between the island numbers of the hub island gene segment and each island gene segment. An example of the mutation operator is shown in Fig. 5.

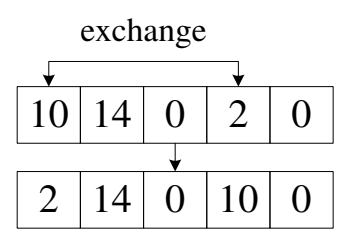

(a) The first mutation operator (Take centre islands gene segment as example)

exchange
\begin{tabular}{|l|l|l|l|l|l|l|l|l|l|l|}
\hline 6 & 4 & 0 & 0 & 1 & 7 & 3 & 0 & 0 & 0 & 5 \\
\hline 6 & 4 & 3 & 0 & 1 & 7 & 0 & 0 & 0 & 0 & 5 \\
\hline
\end{tabular}

(b) The second mutation operator (Take archipelago 1 gene segment as example)

exchange
\begin{tabular}{|l|l|l|l|l|l|l|l|l|l|l|l|l|l|l|}
\hline 10 & 14 & 0 & 2 & 0 \\
\hline 10 & 14 & 0 & 3 & 0
\end{tabular}
\begin{tabular}{|l|l|l|l|l|l|l|l|l|l|l|l|l|}
\hline 6 & 4 & 0 & 0 & 1 & 7 & 3 & 0 & 0 & 0 & 5 \\
\hline 6 & 4 & 0 & 0 & 1 & 7 & 2 & 0 & 0 & 0 & 5 \\
\hline
\end{tabular}

(c) The third mutation operator (Take the mutation between centre islands gene segment and archipelago 1 gene segment as example)

Fig. 5. mutation operator

\section{Case study}

\subsection{Basic data}

In this subsection, one example is put forward to assess the effectiveness of the method, in which 3 sets of archipelagos are assumed and the number of islands is 10, 7 and 5, respectively. The coordinates of every island are shown in table 2. The alternative ship sizes are 100, 500, 1000 and 5000 tons. Table 3 shows the daily consumption of each island. Table 4 shows the relevant costs of ship and wharf construction. The total time of system operation is 20 years, and $\Delta t$ of the inventory system is 5 days. 
Table 2 Coordinates of every island

\begin{tabular}{cc|cc|cc|cc}
\hline Island & $\begin{array}{c}\text { Coordinates } \\
\text { (nautical mile) }\end{array}$ & Island & $\begin{array}{c}\text { Coordinates } \\
\text { (nautical mile) }\end{array}$ & Island & $\begin{array}{c}\text { Coordinates } \\
\text { (nautical mile) }\end{array}$ & Island & $\begin{array}{c}\text { Coordinates } \\
\text { (nautical mile) }\end{array}$ \\
\hline $\mathrm{O}^{\#}$ & $(8,643)$ & $6^{\#}$ & $(123,453)$ & $12^{\#}$ & $(254,463)$ & $18^{\#}$ & $(253,87)$ \\
$1^{\#}$ & $(60,515)$ & $7^{\#}$ & $(77,454)$ & $13^{\#}$ & $(441,397)$ & $19^{\#}$ & $(302,85)$ \\
$2^{\#}$ & $(106,508)$ & $8^{\#}$ & $(42,437)$ & $14^{\#}$ & $(257,442)$ & $20^{\#}$ & $(227,73)$ \\
$3^{\#}$ & $(108,498)$ & $9^{\#}$ & $(60,477)$ & $15^{\#}$ & $(222,417)$ & $21^{\#}$ & $(148,67)$ \\
$4^{\#}$ & $(134,490)$ & $10^{\#}$ & $(74,478)$ & $16^{\#}$ & $(216,144)$ & $22^{\#}$ & $(142,21)$ \\
$5^{\#}$ & $(117,467)$ & $11^{\#}$ & $(223,453)$ & $17^{\#}$ & $(222,103)$ & & \\
\hline
\end{tabular}

Table 3 Daily consumption of every island

\begin{tabular}{|c|c|c|c|c|c|c|c|}
\hline Island & $\begin{array}{l}\text { Daily consumption } \\
\text { (ton) }\end{array}$ & Island & $\begin{array}{l}\text { Daily consumption } \\
\text { (ton) }\end{array}$ & Island & $\begin{array}{l}\text { consumption } \\
\text { (ton) }\end{array}$ & Island & $\begin{array}{l}\text { consumption } \\
\text { (ton) }\end{array}$ \\
\hline $1^{\#}$ & 21 & $7^{\#}$ & 52 & $13^{\#}$ & 31 & $19^{\#}$ & 61 \\
\hline $2^{\#}$ & 31 & $8^{\#}$ & 171 & $14^{\#}$ & 40 & $20^{\#}$ & 181 \\
\hline $3^{\#}$ & 191 & $9^{\#}$ & 40 & $15^{\#}$ & 12 & $21^{\#}$ & 80 \\
\hline $4^{\#}$ & 33 & $10^{\#}$ & 59 & $16^{\#}$ & 96 & $22^{\#}$ & 104 \\
\hline $5^{\#}$ & 132 & $11^{\#}$ & 25 & $17^{\#}$ & 120 & & \\
\hline $6^{\#}$ & 119 & $12^{\#}$ & 10 & $18^{\#}$ & 73 & & \\
\hline
\end{tabular}

Table 4 Estimate table of relevant cost

\begin{tabular}{|c|c|c|c|c|}
\hline $\begin{array}{l}\text { Ship size } \\
\text { (tonnage class) }\end{array}$ & $\begin{array}{l}\text { Construction costs } \\
\text { (thousand yuan) }\end{array}$ & $\begin{array}{l}\text { Daily operation costs } \\
\text { (thousand yuan } \\
\text { /month) }\end{array}$ & $\begin{array}{c}\text { Voyage costs } \\
\text { (yuan/nautical mile) }\end{array}$ & $\begin{array}{l}\text { Corresponding terminal } \\
\text { construction costs } \\
\text { (thousand yuan) }\end{array}$ \\
\hline 100 & 400 & 6.8 & 8 & 20000 \\
\hline 500 & 1,500 & 14 & 25 & 60,000 \\
\hline 1,000 & 2,800 & 18.8 & 30 & 100,000 \\
\hline 5,000 & 12,000 & 40 & 70 & 200,000 \\
\hline
\end{tabular}




\subsection{Results}

We use Matlab 6.5 to run the SC-GA algorithm, calculating in the environment of windows XP, AMD Athlon (tm) II X2 240 Processor $2.81 \mathrm{GHz}, 2 \mathrm{~GB}$ memory. Set the population size pop $=30$, crossover rate $p_{c}=0.5$, mutation rate $p_{m}=0.055$, and maximum generation MaxGen $=3000$.

The optimal result was obtained after 2815 generations, and the convergence process is shown in Fig. 6. The result shows that the $3^{\#}, 14^{\#}$, and $20^{\#}$ islands are selected as the hub islands of the three sets of islands; there are 12 ships equipped in the islands shipping network: 2 ships of 5000 tons, 1 ship of 1000 tons, 5 ships of 500 tons, and 4 ships of 100 tons. There are 28 wharfs equipped in the islands shipping network. Four wharfs of 5000 tons, 1000 tons, 500 tons, and 100 tons are equipped on $3^{\#}$ island, two wharfs of 5000 tons and 100 tons are equipped on $14^{\#}$ island, two wharfs of 5000 tons and 500 tons are equipped on $20^{\#}$ island, and every satellite island equips a wharf of 1000 tons, 500 tons, or 100 tons. The inventory capacity of all islands is 27210 tons. The optimized routings are shown in tables $5 \sim 8$. The wharf, the inventory capacity, and the cycle supply of every island are shown in table 9. The islands shipping network is shown in Fig. 7.

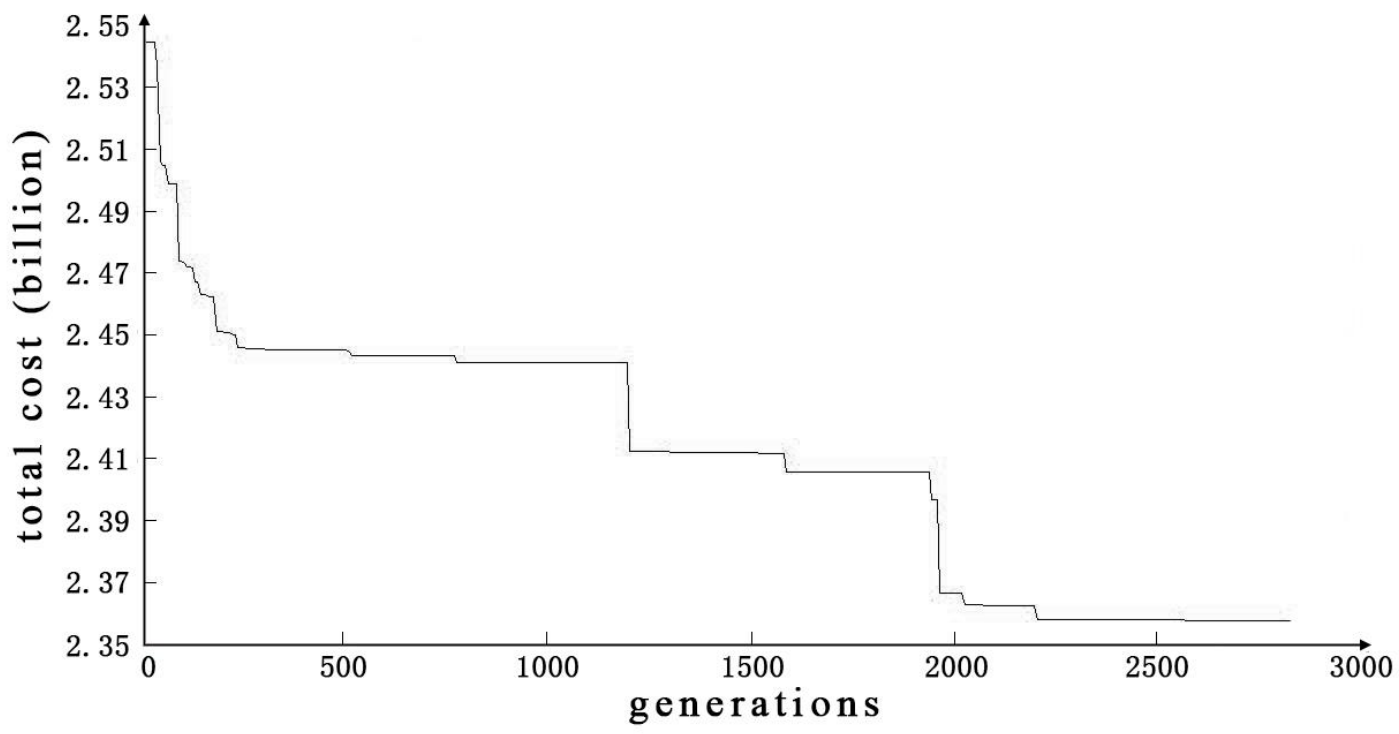

Fig. 6. The algorithm converge process

Table 5 Route configuration of shipping network from the mainland to every hub island

Route The cycle transport route The back-and-forth route




\begin{tabular}{ccc}
\hline & $\begin{array}{c}\text { of the mainland to centre } \\
\text { islands }\end{array}$ & of the mainland to centre \\
& $3^{\#}, 14^{\#}$ & $20^{\#}$ \\
\hline Islands and sequence & 5,000 & 5,000 \\
Ship size (tonnage class) & 5 & 6 \\
Schedule (days) & & \\
\hline
\end{tabular}

Table 6 Routes of shipping network in archipelago 1 from hub island to every satellite island

\begin{tabular}{cccccc}
\hline & Cycle transport & Back-and-forth & Back-and-forth \\
Route & route I & transport route & Back-and-forth & Back-and-forth \\
transport route & transport route & transport route \\
& & group II & group III & group IV \\
\hline Island and running order & $7^{\#}, 9^{\#}, 10^{\#}$ & $1^{\#}$ & $2^{\#}, 4^{\#}$ & $5^{\#}, 6^{\#}$ & $8^{\#}$ \\
Ship size (tonnage class) & 500 & 100 & 100 & 500 & 1,000 \\
Schedule (day) & 3 & 4 & 3 & 3 & 4 \\
\hline
\end{tabular}

Table 7 Routes of shipping network in archipelago 2 from hub island to every satellite island

\begin{tabular}{ccc}
\hline Route & $\begin{array}{c}\text { Back-and-forth } \\
\text { transport route } \\
\text { group V }\end{array}$ & $\begin{array}{c}\text { Back-and-forth } \\
\text { transport route } \\
\text { group VI }\end{array}$ \\
\hline Island and running order & $11^{\#}, 12^{\#}, 15^{\#}$ & $13^{\#}$ \\
Ship size (tonnage class) & 100 & 100 \\
Schedule (day) & 4 & 3 \\
\hline
\end{tabular}

Table 8 Routes of shipping network in archipelago 3 from hub island to every satellite island

\begin{tabular}{cccc}
\hline Route & $\begin{array}{c}\text { Cycle transport } \\
\text { route II }\end{array}$ & $\begin{array}{c}\text { Back-and-forth } \\
\text { transport route } \\
\text { group VII }\end{array}$ & $\begin{array}{c}\text { Back-and-forth } \\
\text { transport route } \\
\text { group VIII }\end{array}$ \\
\hline Island and sequence & $18^{\#}, 19^{\#}$ & $16^{\#}, 21^{\#}$ & $17^{\#}, 22^{\#}$ \\
Ship size (tonnage class) & 500 & 500 & 500 \\
Schedule (days) & 3 & 5 & 4 \\
\hline
\end{tabular}


Table 9 The wharf, inventory capacity and cycle supply of every island

\begin{tabular}{|c|c|c|c|c|c|}
\hline Archipelago & Island & $\begin{array}{l}\text { Number } \\
\text { (berth) }\end{array}$ & $\begin{array}{c}\text { Berth } \\
\text { (tonnage class) }\end{array}$ & $\begin{array}{c}\text { Storage capacity } \\
\text { (ton) }\end{array}$ & $\begin{array}{r}\text { Supply } \\
\text { (ton) }\end{array}$ \\
\hline \multirow{10}{*}{ Archipelago 1} & $1^{\#}$ & 1 & 100 & 189 & 84 \\
\hline & $2^{\#}$ & 1 & 100 & 248 & 93 \\
\hline & $3^{\#}$ & 4 & $100,500,1,000,5,000$ & 8,490 & 4,245 \\
\hline & $4^{\#}$ & 1 & 100 & 264 & 99 \\
\hline & $5^{\#}$ & 1 & 500 & 1056 & 396 \\
\hline & $6^{\#}$ & 1 & 500 & 952 & 357 \\
\hline & $7^{\#}$ & 1 & 500 & 416 & 156 \\
\hline & $8^{\#}$ & 1 & 1,000 & 1539 & 684 \\
\hline & $9^{\#}$ & 1 & 500 & 320 & 120 \\
\hline & $10^{\#}$ & 1 & 500 & 472 & 177 \\
\hline \multirow{5}{*}{ Archipelago 2} & $11^{\#}$ & 1 & 100 & 225 & 100 \\
\hline & $12^{\#}$ & 1 & 100 & 90 & 40 \\
\hline & $13^{\#}$ & 1 & 100 & 248 & 93 \\
\hline & $14^{\#}$ & 2 & $100,5,000$ & 1,180 & 590 \\
\hline & $15^{\#}$ & 1 & 100 & 108 & 48 \\
\hline \multirow{7}{*}{ Archipelago 3} & $16^{\#}$ & 1 & 500 & 960 & 480 \\
\hline & $17^{\#}$ & 1 & 500 & 1,080 & 480 \\
\hline & $18^{\#}$ & 1 & 500 & 584 & 219 \\
\hline & $19^{\#}$ & 1 & 500 & 488 & 183 \\
\hline & $20^{\#}$ & 2 & $500,5,000$ & 7,865 & 4,290 \\
\hline & $21^{\#}$ & 1 & 500 & 800 & 400 \\
\hline & $22^{\#}$ & 1 & 500 & 936 & 416 \\
\hline
\end{tabular}




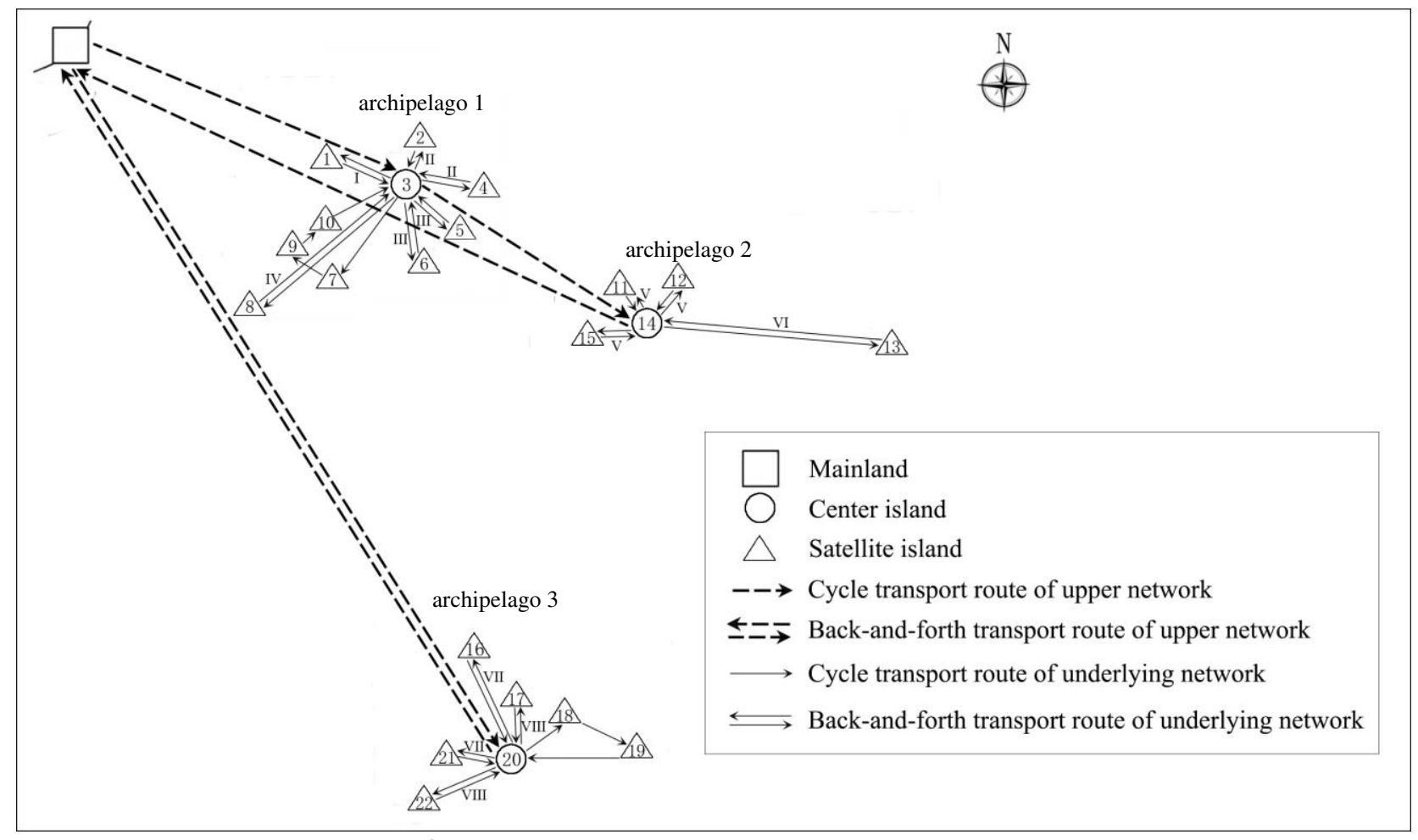

Fig. 7. Shipping network for island

\subsection{Algorithm comparison}

In this subsection, we compare the greedy algorithm and saving algorithm with the SC-GA (Table 10). The strategy of greedy algorithm, according to the size order of all costs, is to optimize the location of hub islands in terms of the consumption of every island first, then set wharf, then optimize the routings, ship size, and schedule of each route, and then set the inventory system. The strategy of the saving algorithm is seeking the minimum transport distance and the minimum ship size of each route. Compared with the greedy algorithm, the ship using cost, the wharf construction cost and the warehouse construction cost of the result of SC-GA is lower, but the shipping cost and the inventory cost are higher; compared with the saving algorithm, the shipping cost, the ship using cost, and the wharf construction cost of the result of SC-GA is lower, but the inventory cost and the warehouse construction cost are higher; however, for the total cost during the total time of system operation, the result of SC-GA can save 59605 thousand yuan over the greedy algorithm and 1025964 thousand yuan over the saving algorithm, and the total cost savings, respectively, are $1.6 \%$ and $28.0 \%$. Thus, SC-GA can take various factors into account and effectively optimize the islands shipping network. 
Table 10 The results of greedy algorithm, saving algorithm and SC-GA (Unit: thousand yuan)

\begin{tabular}{|c|c|c|c|c|c|c|c|}
\hline & & & & & & The total cost & \\
\hline & $\begin{array}{c}\text { Shipping } \\
\text { cost }\end{array}$ & $\begin{array}{l}\text { Ship } \\
\text { using } \\
\text { cost }\end{array}$ & $\begin{array}{c}\text { Wharf } \\
\text { construction } \\
\text { cost }\end{array}$ & $\begin{array}{c}\text { Storage } \\
\text { cost }\end{array}$ & $\begin{array}{l}\text { Warehouse } \\
\text { construction } \\
\text { cost }\end{array}$ & $\begin{array}{l}\text { during the } \\
\text { accounting } \\
\text { period }\end{array}$ & $\begin{array}{l}\text { The rate of } \\
\text { total cost } \\
\text { saving }(\%)\end{array}$ \\
\hline Greedy & $3,835,140$ & 139,794 & $2,640,000$ & 388,009 & 166,565 & $3,717,882$ & 1.6 \\
\hline $\begin{array}{l}\text { aloorithm } \\
\text { Saving }\end{array}$ & 462,108 & 84,192 & $3,690,000$ & 319,123 & 128,819 & $4,684,241$ & 28.0 \\
\hline $\begin{array}{c}\text { algorithm } \\
\text { SC-GA }\end{array}$ & 449,776 & 82,940 & $2,520,000$ & 443,375 & 162,186 & $3,658,277$ & - \\
\hline
\end{tabular}

\subsection{Sensitivity analysis}

To analyse the sensitivity of every cost element to the total cost, we establish a sensitivity analysis model. $\alpha, \beta, \gamma, \delta$ and $\rho$ respectively denote the weight coefficients of shipping cost, ship using cost, wharf construction cost, inventory cost, and warehouse construction cost. Then, the objective function (11) of the cost optimization model can be changed as follows:

$$
\min C_{\text {total }}=\alpha\left(C_{d r}+C_{c y}+C_{\text {mdr }}+C_{\text {mcy }}\right)+\beta C_{\text {ship }}+\gamma C_{\text {port }}+\delta C_{s t f}+\rho C_{s t b}
$$

The value range of $\alpha, \beta, \gamma, \delta$, and $\rho$ is from 0 to 2 . The results for different weight coefficients are shown in table 11.

Table11 The experiment result (Unit: thousand yuan)

\begin{tabular}{|c|c|c|c|c|c|c|c|c|c|c|}
\hline$\alpha$ & $\beta$ & $\gamma$ & $\delta$ & $\rho$ & Transport cost & Ship using cost & $\begin{array}{c}\text { Wharf } \\
\text { construction cost }\end{array}$ & Storage cost & $\begin{array}{c}\text { Warehouse } \\
\text { construction cost }\end{array}$ & $\begin{array}{l}\text { The total cost during } \\
\text { the accounting } \\
\text { period }\end{array}$ \\
\hline 0.2 & 0.2 & 0.2 & 0.2 & 0.2 & 90,376 & 18,938 & 474,000 & 88,903 & 32,562 & 704,779 \\
\hline 0.4 & 0.2 & 0.2 & 0.2 & 0.2 & 159,984 & 21,880 & 504,000 & 95,707 & 36,290 & 817,861 \\
\hline 0.6 & 0.2 & 0.2 & 0.2 & 0.2 & 238,072 & 22,286 & 504,000 & 96,417 & 36,679 & 897,454 \\
\hline 0.8 & 0.4 & 0.2 & 0.2 & 0.2 & 318,965 & 41,816 & 504,000 & 96,962 & 36,978 & 998,721 \\
\hline 1 & 0.6 & 0.2 & 0.2 & 0.2 & 398,706 & 62,724 & 504,000 & 96,962 & 36,978 & $1,099,370$ \\
\hline 1.2 & 0.8 & 0.4 & 0.2 & 0.2 & 476,716 & 87,520 & $1,008,000$ & 97,223 & 37,121 & $1,706,580$ \\
\hline
\end{tabular}




$\begin{array}{ccccccccccc}1.4 & 1 & 0.6 & 0.2 & 0.2 & 552,617 & 109,400 & 1,512,000 & 98,883 & 38,030 & 2,310,930 \\ 1.6 & 1.2 & 0.8 & 0.4 & 0.2 & 637,930 & 125,448 & 2,016,000 & 193,924 & 36,978 & 3,010,280 \\ 1.8 & 1.4 & 1 & 0.6 & 0.2 & 717,671 & 146,356 & 2,520,000 & 290,886 & 36,978 & 3,711,891 \\ 1.8 & 1.6 & 1.2 & 0.8 & 0.4 & 718,625 & 170,515 & 3,024,000 & 387,848 & 73,956 & 4,374,944 \\ 1.8 & 1.8 & 1.4 & 1 & 0.6 & 798,350 & 170,446 & 3,318,000 & 452,562 & 100,332 & 4,839,690 \\ 1.8 & 1.8 & 1.6 & 1.2 & 0.8 & 800,931 & 170,446 & 3,792,000 & 547,090 & 133,051 & 5,443,518 \\ 1.8 & 1.8 & 1.8 & 1.4 & 1 & 809,597 & 149,292 & 4,536,000 & 620,725 & 162,186 & 6,277,800 \\ 1.8 & 1.8 & 1.8 & 1.6 & 1.2 & 810,712 & 149,292 & 4,536,000 & 709,032 & 194,472 & 6,399,508 \\ 1.8 & 1.8 & 1.8 & 1.8 & 1.4 & 809,597 & 149,292 & 4,536,000 & 798,075 & 227,060 & 6,520,024 \\ 1.8 & 1.8 & 1.8 & 1.8 & 1.6 & 809,597 & 149,292 & 4,536,000 & 798,075 & 259,497 & 6,552,461 \\ 1.8 & 1.8 & 1.8 & 1.8 & 1.8 & 809,597 & 149,292 & 4,536,000 & 798,075 & 291,934 & 6,584,898\end{array}$

According to table 10, we perform a linear regression analysis, using $\alpha, \beta, \gamma, \delta$, and $\rho$ as independent variables and using the shipping cost, the ship using cost, the wharf construction cost, the inventory cost, the warehouse construction cost, and the total cost during the total time of system operation as the dependent variables. The corresponding regression coefficients are shown in table 12. The data in the second to sixth columns are the regression coefficients of each cost when the weight coefficients of the cost are regarded as independent variables. We found that the regression coefficient of the total cost during the total time of system operation in the sixth column is higher than that of the other columns, which means that the total cost during the total time of system operation has a higher sensitivity to $\gamma$, that is to say, the impact of the weight coefficient of the wharf construction cost on the optimal solution is greater than that of the other weight coefficients. In the islands shipping network, the wharf scale is determined according to the ship size, and the ship size of every route is determined according to the routing, the schedule of every route, and location of hub islands, so the impact of the transport system, containing route, ship and wharf on the total cost during the total time of system operation is larger compared with the inventory system. In conclusion, more attention should be paid to the optimization of the transportation system and hub island location compared with that of the inventory system when making decisions. 
Table12 Regression coefficient

\begin{tabular}{cccccc}
\hline \multirow{2}{*}{ The dependent variable } & \multicolumn{5}{c}{ The independent variable } \\
\cline { 2 - 6 } & $\alpha$ & $\beta$ & $\gamma$ & $\delta$ & $\rho$ \\
\hline Shipping cost & 7867.1 & -27.6 & 34 & 149.3 & 114.4 \\
Ship using cost & 235.1 & 1596.1 & -37.2 & 0 & -97.9 \\
Wharf construction cost & 500 & 2250 & 49980 & 0 & 1250 \\
$\quad$ Storage cost & 634.9 & -20.8 & -47.5 & 8749.8 & -94.3 \\
Warehouse construction cost & 346 & -11.4 & -18.1 & -57.9 & 3177.6 \\
The total cost during the total time & & & & & 8349.8 \\
of system operation & 9583.1 & 3786.4 & 49911.2 & 8841.2 & \\
\hline
\end{tabular}

\section{Conclusions}

This paper proposes the MLIRP for the islands shipping network. We establish a logistics cost model that considers the location of each island's hub island, the number of routes of the main network and branch network, the running mode of every route and which islands are passed through by each route and the sequence of the islands, ship size and schedule of each route, wharf scale and inventory capacity and cycle supply. Then, we develop the SC-GA to solve the integrated MLIRP model, and the performance of algorithm is assessed by a set of examples. The sensitivity analysis shows that more attention should be paid to the optimization of the transportation system and hub island location comparing with inventory system when making decisions. This paper has important theoretical significance and application value for establishing and optimizing islands shipping networks.

Notably, this paper only studies the shipping transportation in the islands logistics network. In addition, air transportation can also be considered in the network. Therefore, in the further study, we could propose the integrated model of shipping and air transportation, thus enhancing the security of supply in the island logistics network.

\section{Compliance with Ethical Standards}

Funding: This paper was funded by Key Program of National Natural Science Foundation of 
China (42030409).

Conflict of Interest: The authors declare that they have no conflict of interest.

Ethical approval: This paper does not contain any studies with human participants or animals performed by any of the authors.

Informed consent: Informed consent was obtained from all individual participants included in the study.

\section{Authorship contributions}

$\mathrm{Di} \mathrm{Wu}$ is responsible for the creation of the model, design computer programs, implementation of the computer code and supporting algorithms, and finally writing the paper.

Nuo Wang is responsible for the ideas and formulation of overarching research goals and aims.

\section{References}

Agarwal, R., Ergun, O., 2008. Ship scheduling and network design for cargo routing in liner shipping. Transport Sci 42, 175-196.

Agra, A., Christiansen, M., Delgado, A., Hvattum, L.M., 2015. A maritime inventory routing problem with stochastic sailing and port times. Comput Oper Res 61, 18-30.

Ambrosino, D., Scutella, M.G., 2005. Distribution network design: New problems and related models. Eur J Oper Res 165, 610-624.

Brouer, B.D., Desaulniers, G., Pisinger, D., 2014. A matheuristic for the liner shipping network design problem. Transport Res E-Log 72, 42-59.

Christiansen, M., Fagerholt, K., Flatberg, T., Haugen, O., Kloster, O., Lund, E.H., 2011. Maritime inventory routing with multiple products: A case study from the cement industry. Eur J Oper Res 208, 86-94.

Dong, J.X., Lee, C.Y., Song, D.P., 2015. Joint service capacity planning and dynamic container routing in shipping network with uncertain demands. Transport Res B-Meth 78, 404-421.

Engineer, F.G., Furman, K.C., Nemhauser, G.L., Savelsbergh, M.W.P., Song, J.H., 2012. A 
Branch-Price-and-Cut Algorithm for Single-Product Maritime Inventory Routing. Oper Res 60, $106-122$.

Gelareh, S., Nickel, S., Pisinger, D., 2010. Liner shipping hub network design in a competitive environment. Transport Res E-Log 46, 991-1004.

Guerrero, W.J., Prodhon, C., Velasco, N., Amaya, C.A., 2015. A relax-and-price heuristic for the inventory-location-routing problem. Int T Oper Res 22, 129-148.

Hewitt, M., Nemhauser, G., Savelsbergh, M., Song, J.H., 2013. A branch-and-price guided search approach to maritime inventory routing. Comput Oper Res 40, 1410-1419.

Hsu, C.I., Hsieh, Y.P., 2007. Routing, ship size, and sailing frequency decision-making for a maritime hub-and-spoke container network. Math Comput Model 45, 899-916.

Iakovou, E., Douligeris, C., Li, H., Ip, C., Yudhbir, L., 1999. A maritime global route planning model for hazardous materials transportation. Transport Sci 33, 34-48.

Javid, A.A., Azad, N., 2010. Incorporating location, routing and inventory decisions in supply chain network design. Transport Res E-Log 46, 582-597.

Jayaraman, V., 1998. Transportation, facility location and inventory issues in distribution network design - An investigation. Int J Oper Prod Man 18, 471-+.

Jin, F.J., 2003. Study on Development Strategy of Shipping Centers and Transportation Networks in the Yellow Sea Rim. Chinese Geogr Sci 13, 97-103.

Liu, B.L., Chen, H., Li, Y.H., Liu, X., 2015. A Pseudo-Parallel Genetic Algorithm Integrating Simulated Annealing for Stochastic Location-Inventory-Routing Problem with Consideration of Returns in E-Commerce. Discrete Dyn Nat Soc.

Liu, S.C., Lee, S.B., 2003. A two-phase heuristic method for the multi-depot location routing problem taking inventory control decisions into consideration. Int J Adv Manuf Tech 22, 941-950.

Liu, S.C., Lin, C.C., 2005. A heuristic method for the combined location routing and inventory problem. Int J Adv Manuf Tech 26, 372-381.

Meng, Q., Wang, S.A., 2011. Liner shipping service network design with empty container repositioning. Transport Res E-Log 47, 695-708. 
Nekooghadirli, N., Tavakkoli-Moghaddam, R., Ghezavati, V.R., Javanmard, S., 2014. Solving a new bi-objective location-routing-inventory problem in a distribution network by meta-heuristics. Comput Ind Eng 76, 204-221.

Nozick, L.K., Turnquist, M.A., 2001. Inventory, transportation, service quality and the location of distribution centers. Eur J Oper Res 129, 362-371.

Rakke, J.G., Andersson, H., Christiansen, M., Desaulniers, G., 2015. A New Formulation Based on Customer Delivery Patterns for a Maritime Inventory Routing Problem. Transport Sci 49, $384-401$.

Reinhardt, L.B., Pisinger, D., 2012. A branch and cut algorithm for the container shipping network design problem. Flex Serv Manuf J 24, 349-374.

Ronen, D., 2002. Marine inventory routing: shipments planning. J Oper Res Soc 53, 108-114.

Shen, Z.J.M., Coullard, C., Daskin, M.S., 2003. A joint location-inventory model. Transport Sci 37, $40-55$.

Shen, Z.J.M., Qi, L., 2007. Incorporating inventory and routing costs in strategic location models. Eur J Oper Res 179, 372-389.

Song, J.H., Furman, K.C., 2013. A maritime inventory routing problem: Practical approach. Comput Oper Res 40, 657-665.

Tran, N.K., Haasis, H.D., 2015. Literature survey of network optimization in container liner shipping. Flex Serv Manuf J 27, 139-179.

Tuzun, D., Burke, L.I., 1999. A two-phase tabu search approach to the location routing problem. Eur J Oper Res 116, 87-99.

Uggen, K.T., Fodstad, M., Norstebo, V.S., 2013. Using and extending fix-and-relax to solve maritime inventory routing problems. Top 21, 355-377.

Viswanathan, S., Mathur, K., 1997. Integrating routing and inventory decisions in one-warehouse multiretailer multiproduct distribution systems. Manage Sci 43, 294-312.

Wang, S.A., Liu, Z.Y., Meng, Q., 2013. Systematic Network Design for Liner Shipping Services. Transport Res Rec, 16-23.

Wang, S.A., Meng, Q., 2014. Liner shipping network design with deadlines. Comput Oper Res 41, 
$140-149$.

Wu, T.H., Low, C., Bai, J.W., 2002. Heuristic solutions to multi-depot location-routing problems. Comput Oper Res 29, 1393-1415.

Xu, X.P., Hu, J.H., Liu, F., 2007. Empirical analysis of the ship-transport network of China. Chaos 17. 
Figures

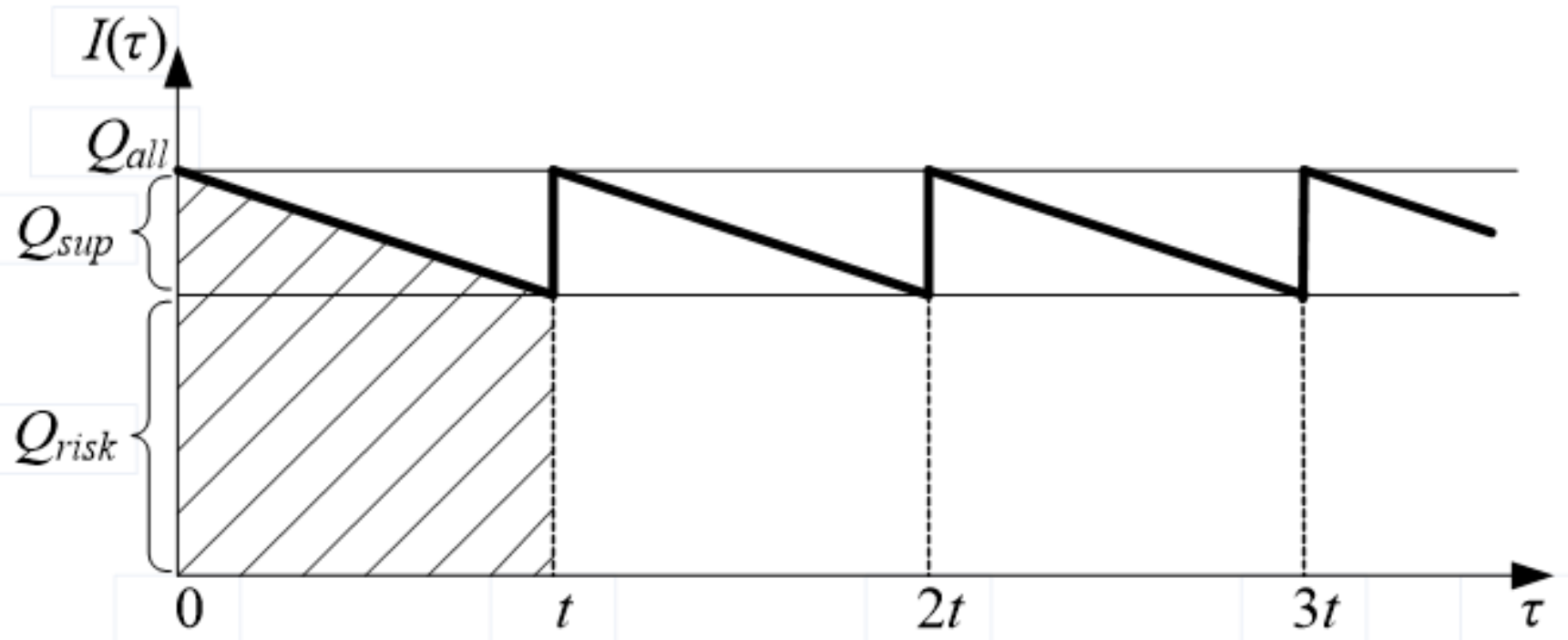

Figure 1

Inventory state

chromosome:

\begin{tabular}{|c|c|c|c|c|c|c|c|c|c|c|c|}
\hline center island gene segment: & 10 & 14 & 0 & 2 & 0 & & & & & & \\
\hline archipelago 1 gene segment: & 6 & 4 & 0 & 0 & 1 & 7 & 3 & 0 & 0 & 0 & 5 \\
\hline archipelago 2 gene segment: & 0 & 11 & 9 & 0 & 0 & 8 & 12 & 0 & & & \\
\hline archipelago 3 gene segment: & 13 & 16 & 0 & 18 & 0 & 0 & 17 & 15 & 0 & & \\
\hline
\end{tabular}

Figure 2

Chromosome expression 


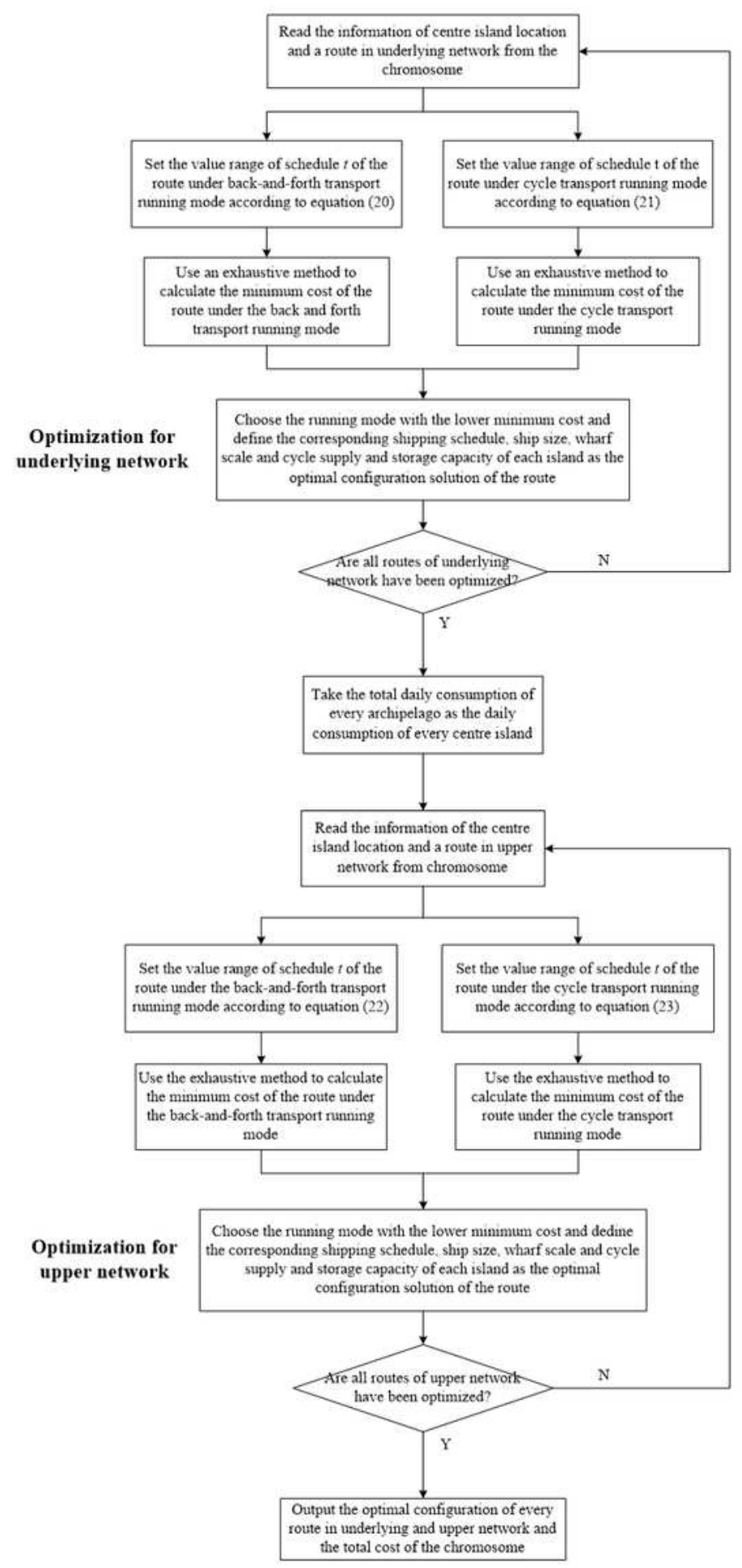

Figure 3

Framework of SC module 


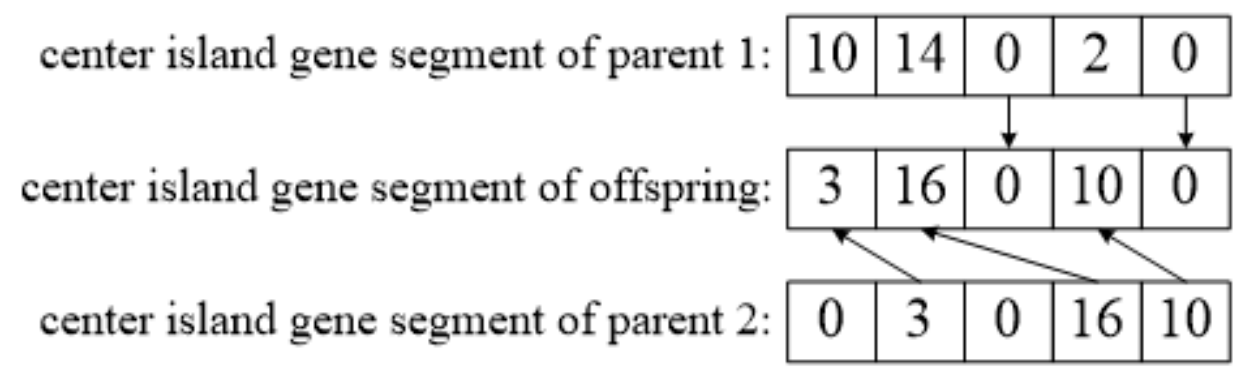

archipelago 1 gene segment of parent 1: \begin{tabular}{|l|l|l|l|l|l|l|l|l|l|l|}
6 & 4 & 0 & 0 & 1 & 7 & 3 & 0 & 0 & 0 & 5 \\
\hline
\end{tabular}

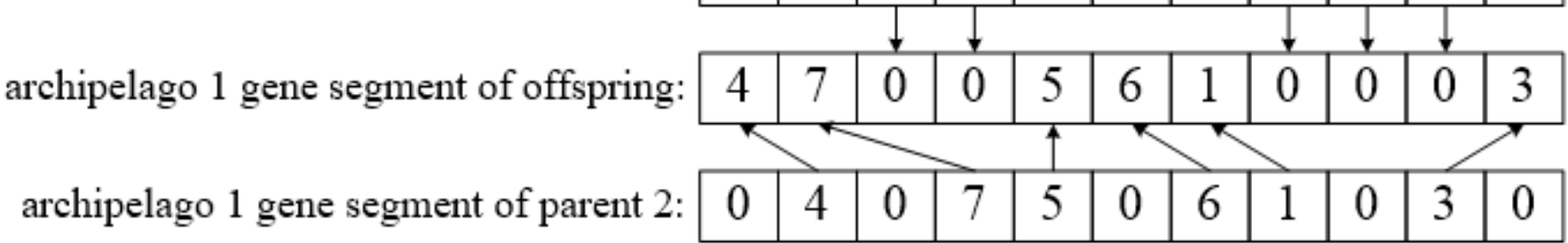

archipelago 2 gene segment of parent 1: \begin{tabular}{|l|l|l|l|l|l|l|l|}
0 & 11 & 9 & 0 & 0 & 8 & 12 & 0 \\
\hline & \multicolumn{1}{|c|}{} & $\downarrow$ & $\downarrow$ & & & \\
\hline
\end{tabular}

archipelago 2 gene segment of offspring:

archipelago 2 gene segment of parent 2: \begin{tabular}{|l|l|l|l|l|l|l|l|}
8 & 9 & 0 & 0 & 12 & 0 & 0 & 11 \\
\hline
\end{tabular}

archipelago 3 gene segment of parent 1: \begin{tabular}{|l|l|l|l|l|l|l|l|l|}
13 & 16 & 0 & 18 & 0 & 0 & 17 & 15 & 0 \\
\hline
\end{tabular}

archipelago 3 gene segment of offspring: \begin{tabular}{|l|l|l|l|l|l|l|l|l|}
15 & 17 & 0 & 16 & 0 & 0 & 18 & 13 & 0 \\
\hline
\end{tabular}

archipelago 3 gene segment of parent 2: \begin{tabular}{|l|l|l|l|l|l|l|l|l|l|}
0 & 15 & 0 & 17 & 16 & 18 & 0 & 0 & 13 \\
\hline
\end{tabular}

Figure 4

crossover operator 


exchange
\begin{tabular}{|l|l|l|l|l|}
\hline 10 & 14 & 0 & 2 & 0 \\
\hline 2 & 14 & 0 & 10 & 0 \\
\hline
\end{tabular}

(a) The first mutation operator (Take centre islands gene segment as example)

\begin{tabular}{|c|c|c|c|c|c|c|c|c|c|c|}
\hline \multicolumn{11}{|c|}{ exchange } \\
\hline 6 & 4 & 0 & 0 & 1 & 7 & 3 & 0 & 0 & 0 & 5 \\
\hline & & & & & $\downarrow$ & & & & & \\
\hline 6 & 4 & 3 & 0 & 1 & 7 & 0 & 0 & 0 & 0 & 5 \\
\hline
\end{tabular}

(b) The second mutation operator (Take archipelago 1 gene segment as example)

exchange
\begin{tabular}{|l|l|l|l|l|l|l|l|l|l|l|l|l|l|l|l|}
\hline 10 & 14 & 0 & 2 & 0 \\
\hline 10 & 14 & 0 & 3 & 0 \\
\hline 6 & 4 & 0 & 0 & 1 & 7 & 3 & 0 & 0 & 0 & 5 \\
\hline 6 & 4 & 4 & 0 & 0 & 1 & 7 & 2 & 0 & 0 & 0 & 5 \\
\hline
\end{tabular}

(c) The third mutation operator (Take the mutation between centre islands gene segment and archipelago 1 gene segment as example)

Figure 5

mutation operator 


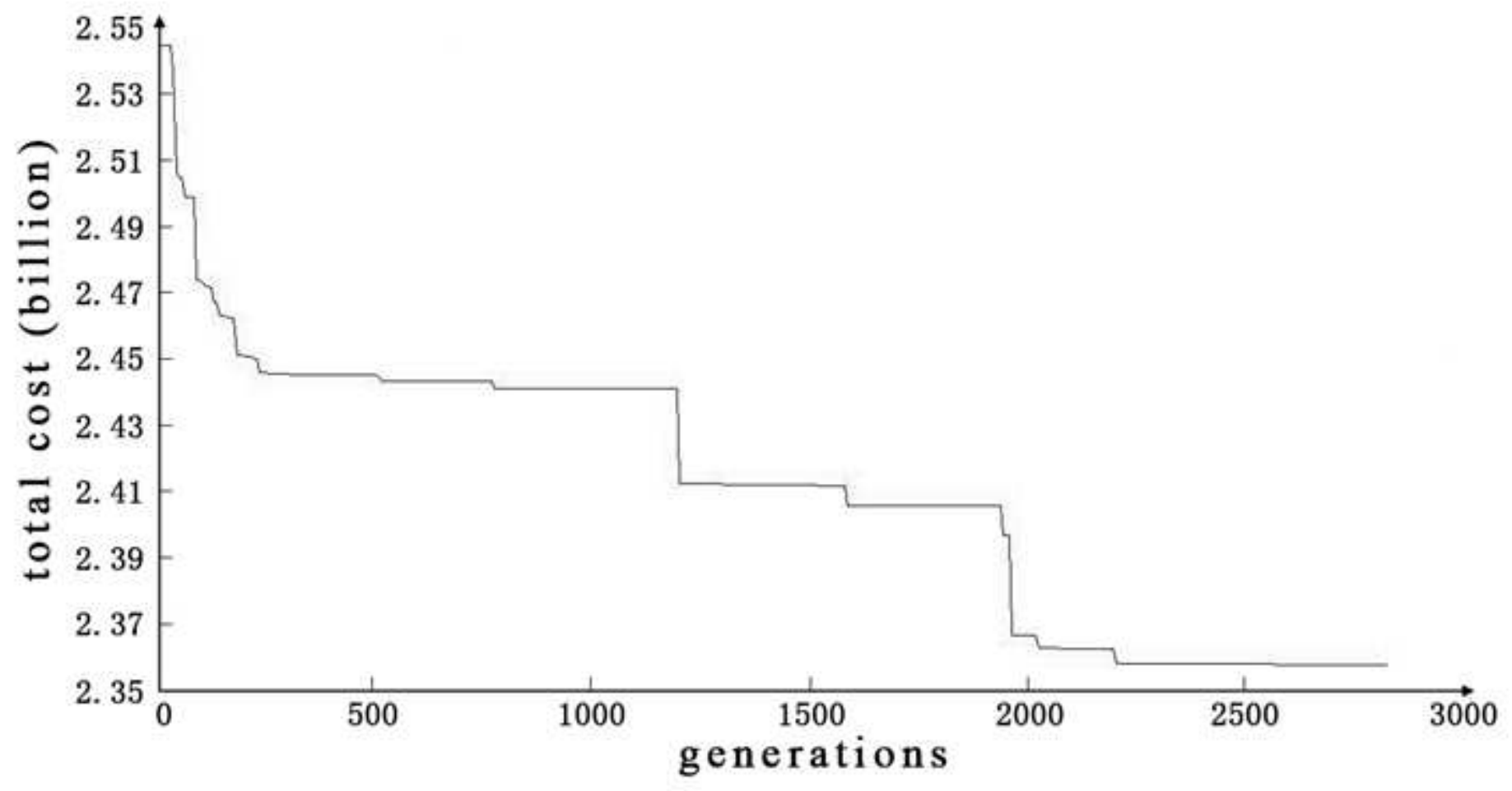

Figure 6

The algorithm converge process

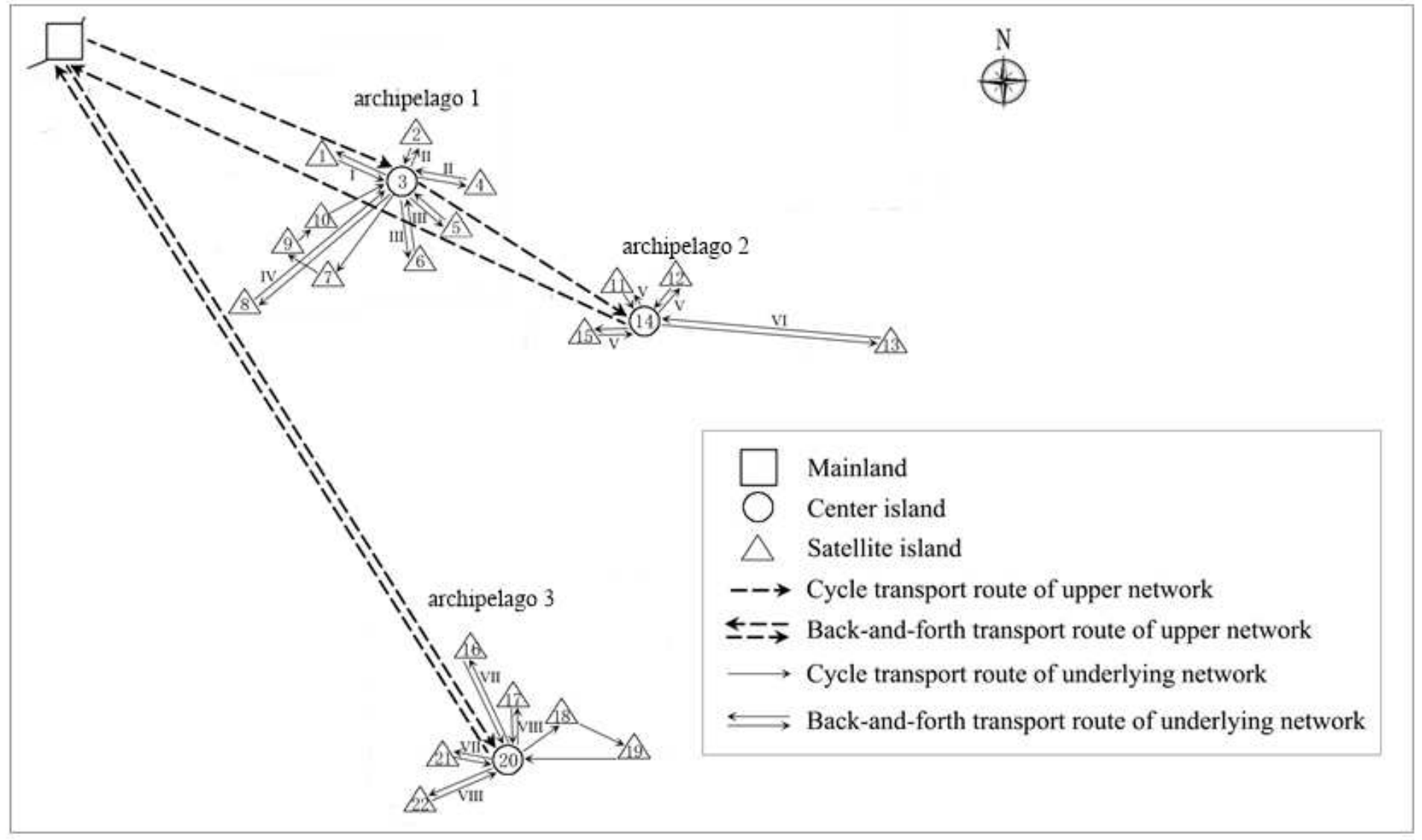

Figure 7 
Shipping network for island 